\author{
ANNA LAMTYCH \\ Uniwersytet Mikołaja Kopernika w Toruniu \\ anna.lamtych@gmail.com
}

ORCID: 0000-0003-3419-2015

\title{
Rozwiązanie umowy o pracę bez wypowiedzenia na skutek popelnienia przestępstwa przez pracownika
}

\author{
Termination of the employment contract with out notice as a result of the employee \\ committing a crime
}

\begin{abstract}
Streszczenie.Rozwiązanie umowy o pracę bez wypowiedzenia $\mathrm{z}$ winy pracownika posiada ogromny wpływ na jego dotychczasową sytuację życiową. Możliwość jednostronnego zakończenia stosunku pracy ze skutkiem natychmiastowym została ograniczona wyłącznie do okoliczności ściśle określonych przez przepisy Kodeksu pracy. Celem niniejszego artykułu jest przedstawienie problematyki jednej $\mathrm{z}$ podstaw nadzwyczajnego zakończenia stosunku pracy, a mianowicie okoliczności popełnienia przestępstwa przez pracownika. W artykule zawarte zostały rozważania dotyczące szczegółowych przesłanek dookreślających przestępne zachowanie pracownika $\mathrm{z}$ uwzględnieniem pojawiających się problemów interpretacyjnych oraz ich spójności z zasadą domniemania niewinności.
\end{abstract}

Słowa kluczowe: prawo pracy; prawo karne; rozwiązanie umowy o pracę; przestępstwo; domniemanie niewinności.

Summary. Termination of the employment contract with out notice due to the fault of the employeehas a hugeimpact on hiscurrent life situation. The possibility of unilateraltermination of employmentrelationship with immediate effectlimited to situations,covered by the application of the provisions of the LaborCode. The purpose of thisarticleis to present the issue of one of the grounds for the extraordinarytermination of anemploymentrelationship, namely the circumstances of the employee committing a crime. The article contains considerations regarding detailed premises specifying the employee's criminal behavior, taking into accounte merging interpretation problems and their consistency with the presumption of innocence.

Keywords: labour law, criminal law, termination of the employmentcontract, crime, presumption of innocence.

Data przesłania artykułu do Redakcji: 30.04.2020 r.

Data akceptacji artykułu przez Redakcję: 17.07.2020 r. 


\section{Wstęp}

Ochrona trwałości stosunku pracy jest jedną z gwarancji praw pracowniczych, której celem jest ochrona przed nagłym pozbawieniem zatrudnienia. Szczególna więź istniejąca między pracownikiem a pracodawcą, wywodzona jest z klasycznego stosunku prawnego ${ }^{1}$. Każdy stosunek prawny, w myśl zasady swobody umów, pozwala w granicach ustawowych dowolnie kształtować jego treść, w tym samą problematykę jego zakończenia ${ }^{2}$. Przepisy zawarte w Kodeksie pracy $^{3}$, dotyczące rozwiązania umowy o pracę, zawierają co do zasady normy o charakterze imperatywnym ${ }^{4}$. Oznacza to, że strony stosunku pracy nie mogą kształtować rozwiązań wskazanych w ustawie w sposóbodmienny, nawet na korzyść pracownika. Prawo pracy, mając na uwadze ochronę zatrudnionych, przewiduje dwa zasadnicze tryby rozwiązania umowy o pracę, tj. rozwiązanie umowy za wypowiedzeniem oraz rozwiązanie umowy bez wypowiedzenia. Pierwszy tryb odpowiada zwykłemu i podstawowemu sposobowi zakończenia relacji między pracownikiem a pracodawcą. Natomiast tryb drugi, polegający na natychmiastowym rozwiązaniu umowy o pracę, stanowi sposób wyjątkowy ${ }^{5}$. Jego zastosowanie, zarówno przez pracownika, jak i pracodawcę, dopuszczalne jest wyłącznie w przypadkach wyraźnie wskazanych przez ustawę, które w swoim stosowaniu podlegają wykładni zawężającej ${ }^{6}$.

Przedmiotem prowadzonych rozważań w niniejszym artykule jest przedstawienie instytucji zakończenia stosunku pracy w przypadku popełnienia przez pracownika przestępstwa. Autor dokona analizy wyłącznie jednej z trzech okoliczności wymienionych w art. 52 Kodeksu pracy, które warunkują możliwość rozwiązania umowy o pracę bez wypowiedzenia $\mathrm{z}$ winy pracownika. Celem autora jest ukazanie zarysu historycznego kształtowania się wskazanej okoliczności, zaprezentowanie przesłanek w warunkach, których musi być popełnione przestępstwo oraz analiza ich zgodności z Konstytucją ${ }^{7}$ i zasadami postępowania karnego. Autor przedstawi również postulaty de lege ferenda, których celem jest zachowanie spójności norm prawa pracy z innymi gałęziami prawa. Przedstawiona analiza zostanie dokonana $\mathrm{w}$ oparciu o obowiązujące przepisy prawa, szeroką praktykę orzeczniczą oraz poglądy doktryny.

\footnotetext{
${ }^{1}$ A. Rycak, Powszechna ochrona trwałości stosunku pracy, Warszawa 2013, s. 53.

${ }^{2}$ L. Florek, Ustawa i umowa w prawie pracy, Warszawa 2010, s. 104.

${ }^{3}$ Ustawa z dnia 26 czerwca 1974 r. - Kodeks pracy (tekst jedn.: Dz.U. z 2019 r. poz. 1040).

${ }^{4}$ Wyrok Sądu Najwyższego z dnia 6 grudnia 2001 r., I PKN 720/00, OSNAPiUS 2003, nr 22, poz. 546.

${ }^{5}$ Wyrok Sądu Najwyższego z dnia 2 czerwca 1997 r., I PKN 193/97, OSNAPiUS 1998, nr 9, poz. 269.

${ }^{6}$ A. Wypych-Żywicka, P. Prusinowski, P. Nowik., Ustanie umownego stosunku pracy, w: System Prawa Pracy, red. K.W. Baran,Tom II. Indywidualne prawo pracy. Część ogólna, G. Goździewicz, Warszawa 2017, s. 604.

${ }^{7}$ Konstytucja Rzeczypospolitej Polskiej z dnia 2 kwietnia 1997 r. (Dz.U. z 1997 nr 78, poz. 483).
} 


\section{Rys historyczny}

Instytucje odnoszące się do problematyki rozwiązania umowy z pracownikiem bez zachowania okresu wypowiedzenia zostały wpisane do polskich aktów prawnych bardzo szybko. Za pierwsze regulacje, które podmiotowo objęły wszystkich pracowników zatrudnionych na podstawie umowy, uznaje się dwa rozporządzenia Prezydenta Rzeczypospolitej Polskiej z roku $1928^{8}$. Wcześniejsze rozwiązania prawne skierowane były wyłącznie do wskazanych grup pracowników, wyróżnionych na podstawie cech szczególnych, takich jak macierzyństwo lub pełnienie służby wojskowej ${ }^{9}$. Przywołane rozporządzenia z 1928 r. pozwalały pracodawcy rozwiązać umowę o pracę bez wypowiedzenia $\mathrm{z}$ ważnych powodów lub $\mathrm{z}$ winy przeciwnej strony ${ }^{10}$. Jako katalog przykładowych zdarzeń wymienione zostały sytuacje, w których pracownik nadużył zaufania pracodawcy czy też znieważył go lub dokonał obrazy ${ }^{11}$. Jednakże żaden z dotychczasowych przepisów nie wprowadzał wyraźnej możliwości natychmiastowego rozwiązania umowy z pracownikiem, w przypadku popełnienia przez niego przestępstwa.

Taki stan rzeczy uległ przekształceniu w okresie Polski powojennej. Pamiętać należy, iż tamtejsza rzeczywistość dokonała nowegospojrzenia na pracę, która miała być prawem, obowiązkiem i sprawą honoru każdego obywatela ${ }^{12}$. Wraz z wejściem w życie dekretu z dnia 8 stycznia 1952 r. ${ }^{13}$, w sposób kompletny określono instytucję natychmiastowego rozwiązania umowy o pracę przez podmiot zatrudniający ${ }^{14}$. To właśnie art. 2 pkt. 1 dekretu jako pierwszy wymienił okoliczność popełnienia przestępstwa przez pracownika, jako przesłankę stanowiącą podstawę, do rozwiązania z nim umowy w trybie natychmiastowym. Podstawowym czynnikiem, który przyczynił się do wprowadzenia wskazanej okoliczność, byłapotrzeba szczególnej ochrony mienia społecznego, które w dobiegospodarki centralnie planowanej, było przedmiotem licznych zamachów i kradzieży ${ }^{15}$.Po zmianach ustrojowych

\footnotetext{
${ }^{8}$ Rozporządzenie Prezydenta Rzeczypospolitej z dnia 16 marca 1928 r. o umowie o pracę pracowników umysłowych (Dz.U. z 1928 r. nr 35 poz. 323) oraz Rozporządzenia Prezydenta Rzeczypospolitej z dnia 16 marca 1928 r. o pracę robotników (Dz.U. z 1928 r. nr 35 poz. 324).

${ }^{9}$ L. Mitrus, Wypowiedzenie umowy o prace z przyczyn dotyczacych pracownika, Warszawa 2018, s. 11.

${ }^{10}$ Zgodnie z art. 16 Rozporządzenia Prezydenta Rzeczypospolitej z dnia 16 marca 1928 r. o umowie o pracę robotników za ważne powody uważano wszelkie okoliczności, które ze względu na dobre obyczaje lub zasady dobrej wiary upoważniały jedną ze stron do dostąienia od umowy.

${ }^{11}$ Art. 18 RozporządzeniaPrezydenta Rzeczypospolitej z dnia 16 marca 1928 r. o umowie o pracę robotników (Dz.U. z 1928 r. nr 35 poz. 324).

${ }^{12}$ Art. 14 Konstytucji Polskiej Rzeczypospolitej Ludowej z dnia 22 lipca 1952 r. (Dz.U. z 1952 r. nr 22 poz. 232).

${ }^{13}$ Dekret z dnia 18 stycznia1956 r o ograniczeniu dopuszczalności rozwiązywania umów o pracę bez wypowiedzenia oraz o zabezpieczeniu ciągłości pracy (Dz.U. z 1956 r. nr 2 poz. 11).

${ }^{14}$ W. Piotrowski, Rozwiazanie stosunku pracy, Warszawa 1959, s. 50.

${ }^{15}$ T. Rybicki, Rozwiazanie umowy o pracę bez wypowiedzenia na skutek popetnienia przestęstwa przez pracownika, Warszawa 1977, s. 39.
} 
i przejściu na model gospodarki wolnorynkowej, omawiana przesłanka została utrzymana w Kodeksie pracy z 1974 r. i nadal stanowi jedną z podstaw natychmiastowego zwolnienia. Obecnie jej istnienie argumentuje się niemożliwością zachowania dalszej spójności pracy oraz utratą zaufania do działań pracownika, który dopuścił się przestępstwa ${ }^{16}$.

\section{Przesłanki rozwiązania umowy bez wypowiedzenia $z$ winy pracownika na skutek popełnienia przez niego przestępstwa}

Ustawodawca w art. 52 Kodeksu pracy obok samego wskazania na okoliczność popełnienia przestępstwa, wskazuje warunki,w których musi być ono dokonane. Odnosząc się do brzmienia przepisu, można wyróżnić cztery przesłanki. Po pierwsze, czyn dokonany przez pracownika musi być przestępstwem. Po drugie, przestępstwo musi być popełnione w czasie trwania umowy o pracę. Po trzecie, popełnienie przestępstwa uniemożliwia dalsze zatrudnienie pracownika na zajmowanym stanowisku. Po czwarte, popełnione przestępstwo jest oczywiste lub zostało stwierdzone prawomocnym wyrokiem. Popełnienie przestępstwa przez pracownika staje się podstawą warunkującą możliwość natychmiastowego zakończenia z nim umowy o pracę, dopiero wtedy, gdy spełnia ono wszystkie wskazane powyżej przesłanki.

W poniższych podrozdziałach autor dokona kompleksowej analizy wymienionych przesłanek, uwzględniając szeroką praktykę orzeczniczą oraz akcentując istniejące problemy interpretacyjne.

\subsection{Pojęcie przestępstwa}

Aby móc rozpatrywać okoliczność z art. $52 \S 1$ pkt. 2 Kodeksu pracy, konieczne jest popełnienie przez pracownika „przestępstwa”. Samo to pojęcie nie zostało zdefiniowane przez przepisy Kodeksu pracy. Taki stan rzeczy powoduje wątpliwości w zakresie tego, jakie czyny będą kwalifikowane jako „przestępstwo”, a jakie nie. Zdecydowana część doktryny, mimo braku wyraźnego odesłania w przepisie, sięga podefinicję zawartą w art. 7 Kodeksu karnego ${ }^{17}$. Ustawa karna za ,przestępstwo” uznaje bowiem wyłącznie zbrodnię i występek. Stąd za dominujące stanowisko uważa się, iż czynem pozwalającym na natychmiastowe zakończenie stosunku pracy z pracownikiem, jest popełnienie przez niego wyłącznie zbrodni

\footnotetext{
${ }^{16}$ A. Bigaj, Oczywistość popetnienia przestępstwa jako przesłanka rozwiązania umowy o prace bez wypowiedzenia z winy pracownika, Monitor Prawa Pracy 2016, nr 4, s. 189.

${ }^{17}$ Ustawa z dnia 6 czerwca 1997 r. - Kodeks karny (Dz.U. z 1997 nr 88 poz. 553).
} 
lub występku.Należy zaaprobować wskazany wyżej sposób wąskiego interpretowania „przestępstwa”.Ściśle koresponduje on bowiem z wyrażoną przez orzecznictwo zasadą, nakazującą stosowanie wykładni zawężającej w zakresie wyjątkowego sposobu zakończenia stosunku pracy ${ }^{18}$. Jednakże $\mathrm{w}$ tym miejscu konieczne jest zasygnalizowanie, obecnej w literaturze przedmiotu, refleksji nad celowością takiego rozwiązania.

Ujawnia się w tym kontekście problematyka tzw. czynów przepołowionych,będących na granicy przestępstwa i wykroczenia, gdzie warunkiem determinującym ich kwalifikację jest np. wartość dokonanego zaboru mienia lub poziom alkoholu we krwi ${ }^{19}$. Z łatwością można bowiem wyobrazić sobie sytuację, w której pracownik, dokonując kradzieży z całkowitą premedytacją, określa wartość kradzionej rzeczy tak, aby jego czyn nie mógł zostać zakwalifikowany, jako przestępstwo, lecz wyłącznie jako wykroczenie. Powyższy stan faktyczny można dodatkowo dookreślić o dwie okoliczności. Po pierwsze, gdy dana kradzież dokonywana jest wobec mienia pracodawcy oraz po drugie, gdy kradzież dokonywana jest wobec dobra osoby trzeciej. W obu przypadkach niemożliwe jest zastosowanie, jako podstawy do rozwiązania umowy $\mathrm{z}$ pracownikiem, okoliczności wskazanej w art. $52 \S 1$ pkt 2 Kodeksu pracy, gdyż dokonany czyn nie stanowiprzestępstwa. W pierwszym przypadku, zachowanie pracownika może zostać potraktowane, jako ciężkie naruszenie podstawowych obowiązków pracowniczych, co w myśl art. $52 \S 1$ pkt 1 Kodeksu pracy nadal może umożliwiać pracodawcy rozwiązanie z nim umowy $\mathrm{w}$ trybie natychmiastowym ${ }^{20}$. W drugim przypadku pracodawca - jeżeli nawet wykroczenie byłoby oczywiste - nie ma podstaw do natychmiastowego rozwiązania umowy o pracę. Biorąc pod uwagę oba przywołane stany faktyczne, a w szczególności zamierzone działanie pracownika w celu popełnienia (wyłącznie) wkroczenia, zauważyć można słabość instytucji zawartej w art. $52 \S 1$ pkt 2 Kodeksu pracy.

W doktrynie zauważyć można również odosobniony pogląd, wskazujący na konieczność rozumienia użytego w art. $52 \S 1$ pkt 2 Kodeksu pracy pojęcia „przestępstwa”, nie przez pryzmat art. 7 Kodeksu karnego, lecz jako „czyn zabroniony przepisami prawa”21. Takie ujęcie znacząco poszerzałoby zakres definicyjny, obejmując nie tylko zbrodnie i występki, lecz również wykroczenia oraz przestępstwa skarbowe. Mając jednak na uwadze

\footnotetext{
${ }^{18}$ Wyrok Sądu Najwyższego z dnia 21 września 2005 r., II PK 305/04, Legalis nr 70996.

${ }^{19}$ S. Koczur, Zakres przedmiotowy pojęcia ,przestęstwo” w art. 52 \& 1 pkt 2 Kodeksu pracy, Studia z Zakresu Prawa Pracy i Polityki Społecznej 2003/2004, s. 179.

${ }^{20}$ Wyrok Sądu Najwyższego z dnia 12 września 2000 r., I PKN 28/00, OSNAPiUS 2002, nr 7, poz. 161 oraz wyrok Sądu Najwyższego z dnia 10 listopada 1999 r., I PKN 361/99, OSNAPiUS 2001, nr 7 poz. 216.

${ }^{21}$ A. Świątkowski, Kodeks pracy. Komentarz, Warszawa 2018, s. 378.
} 
spójność całego systemu prawnego (wykładnię systemową) oraz zamierzone posługiwanie się określonymi pojęciami przez ustawodawcę, powyższy pogląd uznać należy za nieuzasadniony.

\subsection{Popelnienie przestępstwa w czasie trwania umowy o pracę}

W Kodeksie pracy wyraźnie określono temporalnegranice przestępstwa.Wskazanie ram czasowych jako okres „trwania umowy o pracę” powoduje, że podmiot zatrudniający, co do zasady, nie może powoływać się na przestępstwo, które zostało popełnione przez pracownika przed jego zatrudnieniem u danego pracodawcy ${ }^{22}$. Użyte sformułowanie „trwania umowy o pracę” pozostaje w relacji krzyżowania się z okresem „trwania stosunku pracy”, nie stanowiąc przy tym pojęcia w pełni tożsamego. W myśl art. 26 Kodeksu pracy, co do zasady, dniem rozpoczynającym stosunek pracy, jest dzień określony w umowie o pracę. Przesądza to o tym, że czas trwania umowy o pracę, nie musi pokrywać się z czasem trwania stosunku pracy. W razie braku zbieżności tych dwóch okresów, czas związania umową będzie zawsze dłuższy niż czas trwania stosunku pracy ${ }^{23}$. A więc jeżeli pracownik popełnia przestępstwo, po podpisaniu umowy o pracę, pracodawca ma już możliwość natychmiastowego zakończenia łączącego ich kontraktu, bez względu na to, czy pracownik przystąpił do faktycznego wykonywania pracy ${ }^{24}$.

W kontekście omawianej przesłankizauważyć należy również stanowisko orzecznicze,zgodnie z którym dopuszczalne jest bezzwłoczne rozwiązanie umowy o pracę na podstawie art. $52 \S 1$ pkt 2 Kodeksu pracy wówczas, gdy przestępstwo zostało popełnione przez pracownika $\mathrm{w}$ czasie trwania wcześniejszej umowy $\mathrm{z}$ danym pracodawcą, gdy o popełnieniu przestępstwa pracodawca dowiedział się już w toku realizowanej umowy, zawartej bezpośrednio po ustaniu poprzedniego stosunku pracy ${ }^{25}$. Wykreowana praktyka W znaczący sposób odchodzi od literalnego brzmienia przesłanki określonej w Kodeksie pracy. Dodatkowo na tle przywołanego orzecznictwa poddać można w wątpliwość przestrzeganie zasady ścisłej wykładni stosowania trybu zakończenia stosunku pracy ${ }^{26}$.

\footnotetext{
${ }^{22} \mathrm{P}$. Wąż, Komentarz do art. 52, w: Kodeks pracy. Komentarz, red. K. Walczak, 2020, Legalis teza nr 82. [dostęp: 16.04.2020 r.]

${ }^{23}$ A. Piszczek, Rozwiązanie umowy o prace bez wypowiedzenia przez pracodawce, w: Rozwiazanie umowy o prace bez wypowiedzenia, red. Z. Góral, Warszawa 2017, s. 51.

${ }^{24}$ Tamże, s. 52.

${ }^{25}$ Wyrok Sądu Najwyższego z dnia 12 listopada 2003 r., II PK 625/02, OSNAPiUS 2004, nr 20, poz. 350.

${ }^{26}$ A. Wypych-Żywicka, P. Prusinowski, P. Nowik, Ustanie..., s. 626.
} 


\subsection{Niemożliwość dalszego zatrudnienia na danym stanowisku}

Kolejna przesłanka dookreślająca przestępstwo wskazuje, iż skutkiem czynu pracownika musi być niemożliwość jego dalszego zatrudnienia na danym stanowisku. Nie każde przestępstwo wobec tego uzasadnia bezzwłoczne rozwiązanie umowy o pracę z pracownikiem, a jedynie takie, które dyskwalifikuje jego dalsze zatrudnienie ${ }^{27}$. Art. $52 \S 1$ pkt 2 Kodeksu pracy nie określa w sposób sztywny rodzaju przestępstwa, poprzez wskazanie konkretnego typu lub też rodzaju naruszanego dobra (np. przestępstwo przeciwko mieniu), które wprost przesądzałoby o niemożliwości wykonywania dalszej pracy $^{28}$. Nie ma również znaczenia czy przestępstwo zastało popełnione na szkodę pracodawcy czy osoby trzeciej ${ }^{29}$.Niezbędnym elementem wobec takiego stanu rzeczy jest więc kwestia oceny przestępstwa. Ustawodawca nie wskazuje expressis verbis, który podmiot właściwy jest do jej dokonania oraz jakimi kryteriami powinien się on kierować. Mając na uwadze interes pracodawcyw zachowania spójności pracy, wskazać należy, iż to od jego oceny (a późniejszej decyzji) zależy możliwość zastosowania nadzwyczajnego trybu rozwiązania umowy o pracę. Najtrudniejszą do uchwycenia kwestią pozostaje jednak problematyka kryteriów, jakimi powinien się on posłużyć, przesądzając o niemożliwości dalszego zatrudnienia pracownika. Zaznaczenia wymaga, iż wskazanej „niemożliwości” nie można upatrywać w kategoriach obiektywnych (np. tymczasowe aresztowanie) lub formalnych (np. brak polskiego obywatelstwa). „Niemożliwość” należy odnosić do kategorii subiektywnych, pozostających w związku z miejscem i rodzajem wykonywanej pracy ${ }^{30}$. Brak jakichkolwiek wskazań w tym zakresie ze strony ustawodawcypowoduje niebezpieczeństwo arbitralnej i dowolnej decyzji pracodawcy, co stawia pracownika w zdecydowanie gorszej pozycji.

W doktrynie i judykaturze podejmuje się próby wskazywania pewnych punktów odniesienia, na podstawie których pracodawca powinien ukształtować swoją ocenę. Po pierwsze, sam fakt i charakter popełnionego przestępstwa należy skonfrontować z opinią pozostałych osób, z którymi pracownik do tej pory wspólnie świadczył pracę ${ }^{31}$. Wykazywanie przez załogę dezaprobaty w stosunku do nagannego czynu pracownika może skutecznie doprowadzić do konieczności pozbawienia go dotychczasowego zatrudnienia. Po drugie,

\footnotetext{
${ }^{27}$ D. Klucz, Przestępstwo jako przesłanka bezzwłocznego rozwiąania umowy o pracę, Monitor Prawa Pracy 2006, nr 8, s. 415.

${ }^{28}$ Wyrok Sądu Najwyższego z dnia 19 lipca 1962 r., II PR 203/62, OSNCP 1963, nr 7-8, poz. 165.

${ }^{29}$ Uchwała Sądu Najwyższego z dnia 12 października 1976 r., I PZP 49/76, OSNCP 1977, nr 4, poz. 67.

${ }^{30}$ U. Jackowiak, Utrata zaufania jako podstawa rozwiazania stosunku pracy, Praca i Zabezpieczenie Społeczne 2003, nr 11, s.16. oraz A. Wypych-Żywicka, P. Prusinowski, P. Nowik, Ustanie ..., s. 625.

${ }^{31}$ Uchwała Sądu Najwyższego z dnia 12 października 1976 r., I PZP 49/76, OSNCP 1977, nr 4, poz. 67.
} 
niezbędne jest dokonanie oceny przez pryzmat całokształtu przyszłej działalności zakładu pracy $^{32}$. Powiązane jest to $\mathrm{z}$ koniecznością rozważenia, czy pozostawienie pracownika na dotychczas zajmowanym stanowisku nie spowoduje obiektywnie niższego przychodu dla pracodawcy (np. zmniejszona liczba klientów dokonujących zakupów w czasie trwania zmiany pracownika, który popełnił przestępstwo). Po trzecie,kluczowym w ocenie niemożliwości dalszego zatrudnienia jest odniesienie się do szczególnej więzi łączącej obie strony stosunku pracy, jaką jest zaufanie ${ }^{33}$. Utrata bądź ograniczenie zaufania pracodawcy na skutek popełnionego przestępstwa przez pracownika zaburza stan pewności stosunku pracy i nasuwa wątpliwości, co do prawidłowego wywiązywania się z zobowiązań pracowniczych ciążących na pracowniku ${ }^{34}$.

Dopiero ocena dokonana na podstawie wyżej wskazanych kryteriów pozwala na ograniczenie swobody decyzyjności pracodawcy w zakresie uznania, czy przestępny czyn pracownika uniemożliwia jego dalsze zatrudnienie. Sygnalizowany brak szczegółowych wytycznych ze strony ustawodawcy i posłużenie się bliżej niedookreślonym pojęciem „niemożliwości” należy uznać za praktykę niepożądaną, mając na względzie ochronę trwałości stosunku pracy.

Odnosząc się jeszcze do charakteru omawianej przesłanki, zauważyć należy, iż odgrywa ona znaczącą rolę dla sposobu postrzegania czynu pracownika. Przesłanka ta stanowi bowiem łącznik między przestępstwem penalizowanym przez ustawę karną a stosunkiem pracy. W takim ujęciu możliwość natychmiastowego rozwiązania umowy o pracę przez podmiot zatrudniający nigdy nie może być traktowana jako forma represji wobec pracownika ${ }^{35}$. Należy ją natomiast utożsamiać $\mathrm{z}$ niedającymi się do przezwyciężenia przeszkodami w dalszym utrzymaniu stosunku pracy. Rodzaj popełnionego przestępstwa musi więc pozostawać w ścisłym związku z charakterem zatrudnienia pracownika, a więc powodów niemożliwości dalszego zatrudnienia upatrywać należy wyłącznie w sferze pracowniczej ${ }^{36}$.

\footnotetext{
${ }^{32}$ Tamże.

${ }^{33}$ B. Bury, M. Nawrocki, Postępowanie sqdowe w sprawach z zakresu prawa pracy, Kraków 2019, s. 266.

${ }^{34}$ D. Klucz, Utrata zaufania do pracownika jako przyczyna wypowiedzenia umowy o prace, Monitor Prawa Pracy 2005, nr 9, s. 144.

${ }^{35}$ A. Wypych-Żywicka, P. Prusinowski, P. Nowik, Ustanie ..., s. 625 oraz W. Piotrowski, Rozwiąanie stosunku pracy, w: Studia nad kodeksem pracy, red. W. Jaśkiewicz, Poznań 1975, s. 87.

${ }^{36}$ Wyrok Sądu Najwyższego z dnia 17 kwietnia 1999 r., I PKN 668/98, OSNAPiUS 2000, nr 11, poz. 429.
} 


\subsection{Oczywistość przestępstwa lub jego stwierdzenie prawomocnym wyrokiem}

Przepisy Kodeksu pracy wskazują, iż przestępstwo popełnione przez pracownika musi być oczywiste lub stwierdzone prawomocnym wyrokiem. Obecnie bezsprzeczne jest, że z tak zredagowanej przesłanki wywodzone są dwie okoliczności, tj. przestępstwo oczywiste lub przestępstwo stwierdzone prawomocnym wyrokiem, które mogą występować zarówno łącznie, jak i w sposób od siebie niezależny ${ }^{37}$.Jednakże przestawiony pogląd poprzedzony był sporem doktrynalnym, powstałym krótko po wprowadzeniu do systemu prawnego okoliczności popełnienia przestępstwa jako jednej z podstaw uzasadniającej natychmiastowe zakończenie stosunku pracy ${ }^{38}$. Przedmiotem refleksji była kwestia samodzielności obu wymienionych przesłanek. W myśl odosobnionego poglądu wykładnia przytoczonej przesłanki wskazywała, iż obejmuje ona tylko jedną podstawę do rozwiązania umowy. „Tą podstawą jest popełnienie przestępstwa, za które pracownik został już skazany albo za które zostanie skazany, [..]”. Zaś „ocena popełnienia przestępstwa na podstawie kryterium oczywistości jest tylko prowizorycznym i nieostatecznym sposobem ustalenia faktu popełnienia przestępstwa" ${ }^{\text {39 }}$. Jak zostało zasygnalizowane, pogląd ten został zanegowany przez późniejszą praktykę orzeczniczą.

Przechodząc do szczegółowej analizy całej przesłanki, zauważyć należy, że okoliczność wskazana jako druga, tj. stwierdzenie przestępstwa prawomocnym wyrokiem, nie budzi znaczących wątpliwości. Poza sferą pracowniczą pozostaje bowiem udowodnienie winy pracownika, o której przesądza sąd karny ${ }^{40}$. Odnotować jednak należy obecne w doktrynie skrajne poglądy na temat tego, czy prawomocny wyrok warunkowo umarzający postępowanie może być podstawą rozwiązania stosunku pracy w trybie natychmiastowym. U podstaw twierdzeń, iż wyrok ten nie odpowiada warunkom określonym w opisywanej przesłance, podnoszony jest zarzut braku charakteru orzeczenia skazującego oraz to, że cały przepis art. 52 Kodeksu pracy jako norma wyjątkowa nie może być interpretowany rozszerzająco ${ }^{41}$. Z kolei z drugiej strony, na poparcie, iż wyrok warunkowo umarzający postępowanie może stanowić taką podstawę, uznaje się treść art. 66 Kodeksu karnego ${ }^{42}$. Przytoczony przepis zawiera przesłanki warunkowego umorzenia, gdzie jedną z nich jest wymóg, aby okoliczności

\footnotetext{
${ }^{37}$ A. Piszczek, Rozwiazanie..., s. 55.

${ }^{38}$ A. Bigaj, Oczywistość..., s. 190.

${ }^{39}$ K. Piasecki, Popetnienie przestęstwa jako podstawa rozwiązania umowy o prace bez wypowiedzenia, Palestra 1961, tom 5, nr 4, s. 55.

${ }^{40}$ D. Klucz, Przestęstwo...s. 416.

${ }^{41}$ K. Baran, Komentarz do art. 52, w: Kodeks pracy. Komentarz. Tom I. Art. 1-133, red. K. Baran, Warszawa 2020 , s. 483.

${ }^{42}$ A. Piszczek, Rozwiazanie..., s. 56.
} 
popełnionego czynu nie budziły wątpliwości, a zatem, aby fakt popełnienia przestępstwa nie budził wątpliwości. Taki stan sprawy jest zaś wystarczającą podstawą, aby oskarżonemu przypisać popełnienie określonego czynu ${ }^{43}$. Pogląd tenwydaje się być bardziej przekonujący również z uwagi na literalną treść omawianej przesłanki. Ustawodawca w art. 52 Kodeksu pracy posłużył się określeniem „prawomocnego wyroku” nie zaś „prawomocnego wyroku skazującego". Powołując się na zasadę lege non distinguente, argumenty o braku przymiotu orzeczenia skazującego wobec wyroku warunkowo umarzającego postępowanie, zdają się być nieuzasadnione ${ }^{44}$.

Druga okoliczność, jaką jest oczywistość przestępstwa, już prima facie przesądza o trudnościach definicyjnych i interpretacyjnych. Ustawodawca, posługując się niedookreślonym pojęciem „oczywistości”, tak samo, jak przy przesłance niemożliwości dalszego zatrudnienia, ponownie stwarza niebezpieczeństwo podjęcia arbitralnej decyzji przez pracodawcę. Jednakże brak precyzyjności ustawodawcy, został uzupełniony szeroką praktyką orzeczniczą.Za przestępstwo oczywiste uznaje się takie, w którym nienasuwający wątpliwości stan faktyczny, pozwala na pewne stwierdzenie, że pracownik się go dopuścił ${ }^{45}$. Za stan uzasadniający bezsporność popełnienia przestępstwa uznaje się okoliczności ujęcia pracownika na gorącym uczynku $^{46}$, pozostawanie na miejscu przestępstwa po jego popełnieniu, ujęcia pracownika w czasie bezpośredniego pościgu na terenie lub poza terenem zakładu pracy ${ }^{47}$, jak również nienasuwające zastrzeżeń przyznanie się pracownika do winy ${ }^{48}$, które musi być dodatkowo poparte dowodami lub informacjami pochodzącymi z innych źródel ${ }^{49}$.

Przybliżony powyżej stan pewności pracodawcy o oczywistość popełnionegoprzestępstwaprzez pracownikamusi istnieć przed złożeniem oświadczenia o rozwiązaniu umowy o pracę ${ }^{50}$. Oznacza to, że decyzja pracodawcy, która oparta byłaby wyłącznie na przypuszczeniach, nie stanowi dostatecznej przesłanki do natychmiastowego zakończenia stosunku pracy. Ponadto nawet późniejsze wykazanie oczywistości przestępstwa bądź nawet uprawomocnienie się skazującego wyroku karnego nie powoduje konwalidacji

\footnotetext{
${ }^{43}$ Wyrok Sądu Najwyższego z dnia 20 października 2011 r., III KK 159/11, OSNKW 2012 nr 2, poz. 14.

${ }^{44}$ Zob. szerzej A. Piszczek, Przestępstwo oczywiste lub stwierdzone prawomocnym wyrokiem $w$ świetle art. 52 \& 1 pkt 2 k.p., Praca i Zabezpieczenie Społeczne 2016, nr 11, s. 27-31.

${ }^{45}$ Wyrok Sądu Najwyższego z dnia 31 stycznia 1977 r., I PRN 141/76, OSNCP 1977, nr 8 poz. 147.

${ }^{46}$ Tamże.

${ }^{47}$ K. Baran, Komentarz ...s. 484.

${ }^{48}$ A. Piszczek, Rozwiazanie..., s. 55.

${ }^{49}$ K. Baran, Komentarz .... s. 484.

${ }^{50}$ Postanowienie Sądu Najwyższego z dnia 14 lutego 2007 r., III PZ 7/06, Legalis nr 181923.
} 
bezpodstawnego rozwiązania umowy o pracę, co umożliwia dochodzenie roszczeń przez pracownika z tytułu wadliwego rozwiązania $\mathrm{z}$ nim umowy ${ }^{51}$.

\section{Problematyka przesłanki oczywistości przestępstwa}

W perspektywie przesłanek dookreślających przestępstwo pogłębionej analizy wymaga ostatnia z nich, mianowicie oczywistości jego popełnienia. Kluczowym punktem rozważań jest próba oceny zgodności tak zredagowanej przesłanki z zasadą domniemania niewinności oraz kwestiąnaruszenia dóbr osobistych pracownika.

Ustawodawca, tworząc alternatywny wymóg - oczywistość przestępstwa lub stwierdzenia go prawomocnym wyrokiem - dopuścił możliwość przesądzenia o jego bycie dwóm podmiotom, tj. pracodawcy oraz sądowi karnemu. O ile nie budzi żadnych zastrzeżeń możliwość przypisywania popełnienia przestępstwa w wyroku przez sąd karny, o tyle dokonywanie tego przez pracodawcę, wydawać się może rozwiązaniem kontrowersyjnym. Ponadto - co było sygnalizowane wcześniej - ustawodawca nie stworzył żadnych dodatkowych wskazań, w jaki sposób pracodawca ma rozumieć „oczywistość” przestępstwa. Co więcej, wyraźnie należy zaznaczyć, iż od podmiotu zatrudniającego nie można wymagać wiedzy, w jaką wyposażony jest skład sądu karnego. Może dojść więc do sytuacji, w której przed uprawomocnieniem się wyroku skazującego, pracodawca rozwiązał umowę, uznając uprzednio, iż przestępstwo popełnione przez pracownika było oczywiste. W takim stanie rzeczy poddać $\mathrm{w}$ wątpliwość należy wywiązanie się pracodawcy z obowiązku przestrzegania zasady domniemania niewinności w stosunku do pracownika w okresie od rozwiązania umowy o pracę do chwili uprawomocnienia się wyroku.

Zasada domniemania niewinności w sposób normatywny najszerzej ujęta została w art. 42 ust. 3 Konstytucji, zaś na gruncie procedury karnej jest ona realizowana na podstawie art. 5 Kodeksu postępowania karnego ${ }^{52}$. Główną dyrektywą wywodzoną z omawianej zasady jest obowiązek traktowania osoby za niewinną, dopóki jej wina nie zostanie udowodniona prawomocnym wyrokiem. W przywołanych dziedzinach prawa wyróżnia się jej dwa aspekty w zakresie podmiotów, do których jestskierowana, tj. aspekt

\footnotetext{
${ }^{51}$ Wyrok Sądu Najwyższego z dnia 2 lipca 2015 r., III PK 144/14, OSNKW 2017, nr 5, poz. 54.

${ }^{52}$ Ustawa z dnia 6 czerwca 1997 r. - Kodeks postępowania karnego (tekst jedn.: Dz.U. z 2020 r. poz. 30).
} 
procesowy i pozaprocesowy ${ }^{53}$. Pierwszy z nich wskazuje, że obowiązanymi do przestrzegania zasady domniemania niewinności są organy postępowania karnego. Natomiast aspekt pozaprocesowy za adresatów postrzega ogół społeczeństwa, co bezsprzecznie rozciąga się również na podmioty zatrudniające. Posiadana przez pracodawcę kompetencja do przesądzenia o „oczywistości” przestępstwa jeszcze przed prawomocnym wyrokiem wiąże się również z możliwością przesądzenia o winie pracownika. Zaznaczyć należy, iż nie jest to wyłącznie subiektywne i wewnętrzne przekonanie bądź opinia pracodawcy, lecz osąd istotnie wpływający na byt stosunku pracy.Wobec powyższych rozważań należy stwierdzić, iż przesłanka oczywistości przestępstwa nie spełnia wymogów podyktowanych przez zasadę domniemania niewinności, a zatem pozostaje w sprzeczności z normą konstytucyjną oraz podstawową zasadą procesu karnego ${ }^{54}$.

Decyzja pracodawcy o „oczywistości” przestępstwa musi zostać poprzedzona oceną, ukształtowaną na podstawieprzeprowadzonego postępowania wyjaśniającego. To z kolei nasuwa pytanie, czy samodzielne działania pracodawcyzmierzające do udowodnienia przestępstwa pracownikowi - podejmowane jeszcze przed prawomocnym wyrokiem - nie naruszają jego dóbr osobistych. Mimo zdecydowanej tezy zawartej w uchwale Sądu Najwyższego z dnia 30 marca 1994 r. (I PZP 9/94) ${ }^{55}$, w myśl której prowadzenie postępowania przez pracodawcęsamo przez się nie stanowi działania bezprawnego, a tym samym nie naruszadóbr osobistych pracownika, warte zaakcentowania są argumenty podniesione w uzasadnieniu uchwały.

Sąd Najwyższy uznał, że postępowanie wyjaśniające pracodawcy jest podejmowane w ramach porządku prawnego, a dokładnie na podstawie art. $52 \S 1$ pkt 2 Kodeksu pracy. Taka okolicznośćobala więc domniemanie bezprawności z art. $24 \S 1$ Kodeksu cywilnego ${ }^{56}$, przez co nie może stać się działaniem naruszającym dobra osobiste. Jednakże uchylenie bezprawności nie stanowi zasady absolutnej. W przypadku gdy działania pracodawcy będą polegać na ,przekraczającym niezbędną miarę nadawaniu rozgłosu przestępstwu, które następnie nie znalazło potwierdzenia w postępowaniu karnym, czy też sięganiu (...) do środków zewnętrznych, bez próby wyjaśnienia sprawy z osobą, którą podejrzewa się

\footnotetext{
${ }^{53}$ Zob. szerzej P. Karlik, T. Sroka, P. Wiliński, Komentarz do art. 42, w: Konstytucja RP. Komentarz do art. 186,red. M. Safjan, L. Bosek 2016, Legalis teza 251-254, oraz S. Waltoś, P. Hofmański, Proces karny. Zarys systemu, Warszawa 2016, s. 249-254.

${ }^{54}$ Por. A. Bigaj, Oczywistość..., s. 192, D. Klucz, Przestępstwo... s. 416, S. Pawelec, Zasada domniemania niewinności, w: System Prawa Karnego Procesowego,Tom III. Zasady procesu karnego, red. P. Hofmański, W. Paweł, 2014, LEX nr 4.3.

${ }^{55}$ Uchwała Sądu Najwyższego z dnia 30 marca 1994 r., I PZP 9/94, OSNAPiUS 1994 nr 2, poz. 26.

${ }^{56}$ Ustawa z dnia 23 kwietnia 1964 r. - Kodeks cywilny (tekst jedn.: Dz.U. z 2019 r. poz. 1145).
} 
o popełnienie przestępstwa",traktowane będą jako naruszające dobra osobiste(o ile nie zaistnieją inne przesłanki wyłączające bezprawność np. zezwolenie uprawnionego). Powyższa argumentacja jest $\mathrm{z}$ jednej strony $\mathrm{w}$ pełni uzasadniona, ponieważ wywodzona jest $\mathrm{z}$ logicznego oddziaływania na siebie dwóch przepisów (art. $24 \mathrm{KC}$ oraz art. $52 \S 1$ pkt $2 \mathrm{KP}$ ). Jednakże $\mathrm{z}$ drugiej strony wprowadza znaczącą niepewność $\mathrm{w}$ zakresie tego, kiedy prowadzone przez pracodawcę postępowanie wyjaśniającebędzie działaniem bezprawnym, a kiedy nie. Sformułowana teza przytoczonej uchwały zdaje się nawiązywać wyłącznie do samej abstrakcyjnej możliwości prowadzenia postępowania wyjaśniającego. Natomiast to, czy działania podejmowane $\mathrm{w}$ ramach prowadzonego postępowania wyjaśniającego będą naruszać dobra osobiste pracownika, uzależnione jest od oceny indywidualnego przypadku.

\section{Wnioski}

Rozwiązanie umowy o pracę bez wypowiedzeniaz winy pracownika jest najdalej posuniętym sposobem jednostronnego kształtowania treści stosunku pracy. Mając na uwadze ochronę zatrudnienia, niezbędne było wskazanie przez ustawodawcęokoliczności, w warunkach których tryb ten może zostać zastosowany, jak i również sformułowanie w sposób jasny i precyzyjny przesłanek, które je dookreślają. Patrząc przez powyższy pryzmat na sposób, w jaki ustawodawca określił okoliczność popełnienia przestępstwa przez pracownika, zauważyć można, iż nie odpowiada on w pełni wyznaczonemu wyżej standardowi. Wątpliwości interpretacyjne powstałe na skutek użycia pojęć niezdefiniowanych, takich jak „przestępstwo” oraz niedookreślonych, takich jak „niemożliwość”, „oczywistość”, tworzą zdecydowanie za dużą swobodę dla pracodawcy, stawiając jednocześnie pracownika w gorszej pozycji.

W takim stanie rzeczy pożądanym działaniem legislacyjnym byłoby, po pierwsze jednoznacznewskazanie, w jaki sposób powinno być rozumiane „przestępstwo”, na skutekdokonania wyraźnego odesłania do art. 7 Kodeksu karnego. Zaś po drugie, zasadnym ze strony ustawodawcy byłoby normatywne określenie kryteriów, na podstawie których pracodawca musiałby dokonać oceny „niemożliwości” dalszego zatrudnienia pracownika na zajmowanym stanowisku. Proponowane zmiany istotnie przyczyniłyby się do ograniczenia dowolności pracodawcy w zakresie jednostronnego zakończenia stosunku pracy. Odnosząc się natomiast do przesłanki „oczywistości przestępstwa”, wskazanym działaniem legislacyjnym byłoby ograniczenie się wyłącznie do drugiej $\mathrm{z}$ alternatyw, $\mathrm{tj}$. stwierdzenia 
przestępstwa prawomocnym wyrokiem. Takie działanie zapewniłoby zgodność z zasadą domniemania niewinności, zagwarantowaną każdemu przez Konstytucję Rzeczypospolitej Polskiej, jak i również zapobiegłoby potencjalnej możliwości naruszania dóbr osobistych pracownika.

\section{Bibliografia:}

\section{Literatura}

Baran K., Komentarz do art. 52, w: Kodeks pracy. Komentarz. Tom I. Art. 1-133, red. K. Baran, Warszawa 2020

Bigaj A., Oczywistość popetnienia przestęstwa jako przestanka rozwiazania umowy o prace bez wypowiedzenia z winy pracownika, Monitor Prawa Pracy" 2016, nr 4

Bury B., Nawrocki M., Postepowanie sądowe w sprawach z zakresu prawa pracy, Kraków 2019

Florek L., Ustawa i umowa w prawie pracy, Warszawa 2010

Jackowiak U., Utrata zaufania jako podstawa rozwiazania stosunku pracy, Praca i Zabezpieczenie Społeczne 2003, nr 11

Karlik P., Sroka T., Wiliński P., Komentarz do art. 42, w: Konstytucja RP. Komentarz do art. 1-86, red. M. Safjan, L. Bosek, 2016, Legalis teza 251-254

Klucz D., Przestępstwo jako przesłanka bezzwłocznego rozwiazania umowy o prace, Monitor Prawa Pracy 2006, $\mathrm{nr} 8$

Klucz D., Utrata zaufania do pracownika jako przyczyna wypowiedzenia umowy o prace, Monitor Prawa Pracy 2005, nr 9

Koczur S., Zakres przedmiotowy pojęcia „przestepstwo” w art. 52 \$ 1 pkt 2 Kodeksu pracy, Studia z Zakresu Prawa Pracy i Polityki Społecznej2003/2004

Mitrus L., Wypowiedzenie umowy o prace z przyczyn dotyczacych pracownika, Warszawa 2018

Pawelec S., Zasada domniemania niewinności, w: System Prawa Karnego Procesowego,Tom III. Zasady procesu karnego, red. P. Hofmański, W. Paweł, 2014, LEX nr 4.3

Piasecki K., Popetnienie przestępstwa jako podstawa rozwiąania umowy o pracę bez wypowiedzenia, Palestra 1961, tom 5, nr 4

Piotrowski W., Rozwiazanie stosunku pracy, Warszawa 1959

Piotrowski W., Rozwiazanie stosunku pracy, w: Studia nad kodeksem pracy, red. W. Jaśkiewicz, Poznań 1975

Piszczek A., Przestepstwo oczywiste lub stwierdzone prawomocnym wyrokiem $w$ świetle art. 52 \& 1 pkt. 2 k.p., Praca i Zabezpieczenie Społeczne 2016, nr 11

Piszczek A., Rozwiazanie umowy o prace bez wypowiedzenia przez pracodawce, w: Rozwiazanie umowy o pracę bez wypowiedzenia, red. Z. Góral, Warszawa 2017

Rybicki T., Rozwiazanie umowy o pracę bez wypowiedzenia na skutek popetnienia przestepstwa przez pracownika, Warszawa 1977 
Rycak A., Powszechna ochrona trwatości stosunku pracy, Warszawa 2013

Świątkowski A., Kodeks pracy. Komentarz, Warszawa 2018

Waltoś S., Hofmański P., Proces karny. Zarys systemu, Warszawa 2016

Wąż P., Komentarz do art. 52, w: Kodeks pracy. Komentarz, red. K. Walczak, 2020, Legalis

Wypych-Żywicka A., Prusinowski P, Nowik. P., Ustanie umownego stosunku pracy, w: System Prawa Pracy. Tom II. Indywidualne prawo pracy. Część ogólna, red. K. Baran, G. Goździewicz, Warszawa 2017

\section{Orzecznictwo}

Uchwała Sądu Najwyższego z dnia 12 października 1976 r., I PZP 49/76, OSNCP 1977, nr 4, poz. 67

Uchwała Sądu Najwyższego z dnia 30 marca 1994 r. I PZP 9/94, OSNAPiUS 1994 nr 2, poz. 26

Postanowienie Sądu Najwyższego z dnia 14 lutego 2007 r., III PZ 7/06, Legalis nr 181923

Wyrok Sądu Najwyższego z dnia 6 grudnia 2001 r., I PKN 720/00, OSNAPiUS 2003, nr 22, poz. 546

Wyrok Sądu Najwyższego z dnia 2 czerwca 1997 r., I PKN 193/97, OSNAPiUS 1998, nr 9, poz. 269

Wyrok Sądu Najwyższego z dnia 21 września 2005 r., II PK 305/04, Legalis nr 70996

Wyrok Sądu Najwyższego z dnia 12 września 2000 r., I PKN 28/00, OSNAPiUS 2002, nr 7, poz. 161

Wyrok Sądu Najwyższego z dnia 10 listopada 1999 r., I PKN 361/99, OSNAPiUS 2001, nr 7 poz. 216

Wyrok Sądu Najwyższego z dnia 12 listopada 2003 r., II PK 625/02, OSNAPiUS 2004, nr 20, poz. 350

Wyrok Sądu Najwyższego z dnia 19 lipca 1962 r., II PR 203/62, OSNCP 1963, nr 7-8, poz. 165

Wyrok Sądu Najwyższego z dnia 17 kwietnia 1999 r., I PKN 668/98, OSNAPiUS 2000, nr 11, poz. 429

Wyrok Sądu Najwyższego z dnia 20 października 2011 r., III KK 159/11, OSNKW $2012 \mathrm{nr}$ 2, poz. 14

Wyrok Sądu Najwyższego z dnia 31 stycznia 1977 r., I PRN 141/76, OSNCP 1977, nr 8 poz. 147

Wyrok Sądu Najwyższego z dnia 2 lipca 2015 r., III PK 144/14, OSNKW 2017, nr 5, poz. 54 